Proceedings

\title{
Strategies For the Renaturalization of Tourist Destinations: La Manga Del Mar Menor (Murcia)
}

\section{Enrique Mínguez Martínez ${ }^{1}$}

${ }^{1}$ Universidad de Alicante (UA), Universidad Católica San Antonio de Murcia (UCAM); eminguez@eminguez.com

\begin{abstract}
Along the Mediterranean coastline there are numerous tourist resorts that require a comprehensive renaturalization. La Manga is an environment of great landscape richness where there have been unconnected and unbalanced settlements along the coast. The increase in the size of La Manga has raised the need to naturalize the area. In response to this problem, a new concept has been emerging: Nature Based Solutions (NBS). Strategies such as reforestation, proximity parks, green corridors, permeable soils, roofs and green roofs, would allow this area to reduce its environmental footprint and move towards a more sustainable model.
\end{abstract}

Keywords: Renaturalize; Nature based Solutions (NBS); Green Infrastructure; La Manga del Mar Menor; Landscape

\section{Introduction}

Along the Mediterranean coastline there are numerous mature tourist resorts based on sun and beach tourism that require a comprehensive revitalization. Tourist locations where the survival of the natural environment and urban quality have been threatened by urban developments based on immediate economic return, causing the progressive degradation of these environments and endangering the continuity of the ecosystem. "The environmental value of the territory is always greater than its tourist value and, therefore, tourist activity should never prevent the long-term maintenance of environmental values" (Fariña, 2013) [1].

La Manga del Mar Menor is an environment of great landscape and ecological richness where unconnected and unbalanced settlements have occurred along the coast. Urban landscape made up of houses and hotels empty practically nine months of the year and oversaturated in the summer, which means a loss of the identity of the initial place and an inefficient use of its resources.

As the world urbanizes and warms, urban nature is under increasing pressure. The increasing size of urban environments and their relationship has raised the need to naturalize cities.

According to the United Nations, urban environments account for between $60 \%$ and $80 \%$ of energy consumption and $75 \%$ of global carbon emissions.

Today, more than half of the population lives in cities and it is expected that by 2050 it will reach $70 \%$ of the total population. Such numbers have set off alarm bells and raised the need to restore the lost nature of cities to make them more sustainable.

Accelerated global urbanization, coupled with climate change, threatens the ability of cities to meet the needs of their inhabitants. The climate crisis is devastating. Sea levels are rising and increasing the risk of flooding and erosion in coastal regions around the world. Heat waves are occurring more frequently. 
The solutions to these natural disasters lie in nature, because through nature we can 1 correct bad habits, protect our planet's vulnerable biodiversity and reduce energy consumption.

That nature gains importance in cities should not be understood as a step backwards, but rather as a return to the path we deviated from decades ago in the design of cities. In response to this problem, a new concept framework of the new green economy has become increasingly important: Nature-based Solutions (NBS).

\section{La Manga del Mar Menor}

The environment of La Manga del Mar Menor (Murcia) has been threatened by a process of progressive urbanization, which began in the 1960s and which has not ceased to increase the artificialized surface area until today, resulting in a totally urban environment immersed in a natural ecosystem with the repercussions this supposes for its survival.

La Manga is currently an overcrowded area, with serious mobility and infrastructure problems during the summer season and a semi-abandoned city the rest of the year. Circumstances that devalue the richness of a privileged natural environment (Fig. 1 and 2).

"The only way to reconcile the needs of a new tourism with the conservation of the environment is through a strategy of planning the coastal area which is imaginative and at the same time sensitive to the conditions of the place" (Barba, Pie, 1991) [2].

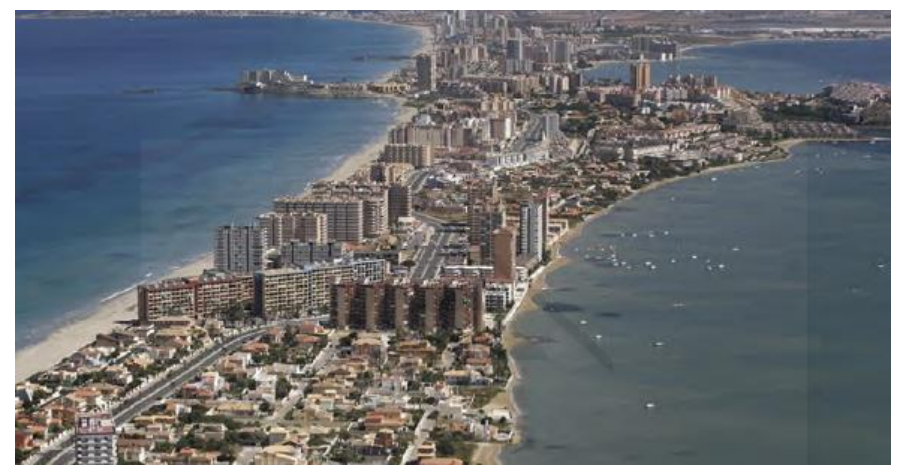

(a)

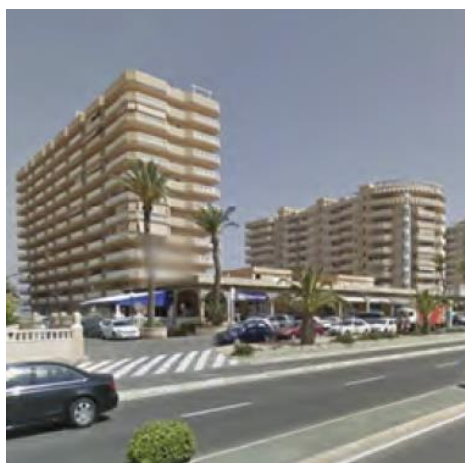

(b)

Fig. 1. (a) La Manga del Mar Menor (Murcia, Spain). Source: Región de Murcia digital; (b) Infrastructure problems. Own elaboration

Throughout La Manga there is a clear deficit of vegetation. The average road section of the Gran Vía is 24 metres. Given the physical characteristics of this environment and its markedly linear character, the Gran Vía could act as a green corridor, generating corridors of shade through the overlapping of trees in rows.

The existence of urban greenery should not be understood as a single-level aspect. In addition to the presence of greenery at street level, vegetation at height should be enhanced by encouraging the connection between green roofs, façades, party walls, balconies and large trees, what Salvador Rueda calls the Connectivity of the network in the urban environment (3 levels) [3].

\section{Nature Based Solutions (NBS)}

More and more cities are developing projects that apply Nature-Based Solutions (NBS) as strategies to respond to challenges such as climate change, biodiversity or air quality.

Nature-based Solutions (NBS), also called Nature-Like Solutions or green and blue infrastructure, help us to increase the resilience of our territory and cities, with the least 
environmental impact, as well as contributing to the conservation of biodiversity and improving our health. They copy or imitate nature's own mechanisms to solve challenges and problems in the management of resources necessary for the proper functioning of cities (water, air, waste, materials, environmental comfort, etc.).

NBS can help to curb the climate crisis. Urban development replaces forests and wetlands with non-porous buildings and infrastructure. When it rains a lot, rainwater that is not absorbed can cause severe flooding. Solutions such as green roofs, rain gardens and artificial wetlands can minimize harmful runoff by absorbing rainwater, reducing flood risks and safeguarding ecosystems. They also keep cities cooler during the summer.

Solutions (NBS) may be different whether they are applied in the natural environment or in the city: public space (streets and/or squares) and buildings.

Natural environment: Regenerative agricultural practices, groundwater recharge, reforestation, artificial wetlands, green belts and naturalized watercourses.

City (streets): Tree rows, permeable surfaces (filter strips, infiltration wells, filter drains and green gutters).

City (squares): Rain gardens, retention ponds, urban parks, permeable surfaces, urban trees, urban gardens and green corridors.

City (buildings): Green roof, green façade and rainwater collection systems.

\section{Strategies for renaturalization in La Manga del Mar Menor}

The great anthropization and artificiality produced in La Manga del Mar Menor has made it necessary to introduce renaturalization strategies, so that nature plays a more prominent role in the built environment in order to project a greener and therefore more sustainable Manga.

It is proposed [4]:

- Strategies for the naturalization of public space. Specific actions, reflected in the Sustainable Urban Development Strategies (EDUSI) "La Manga Abierta 365" [5]., specifically in Strategy E15: The construction of squares by the sea, where three unique public space interventions are proposed: Plaza Galúa, Plaza Zoco de Levante and Plaza Castillos de Mar (Fig. 2 and 3).

In all of them it is proposed to increase the pedestrian space in front of the road by incorporating semi-permeable and permeable soils, integrating Sustainable Draining Urban Soils (SUDs) in the road and improving the proportions of shade by increasing the vegetation.

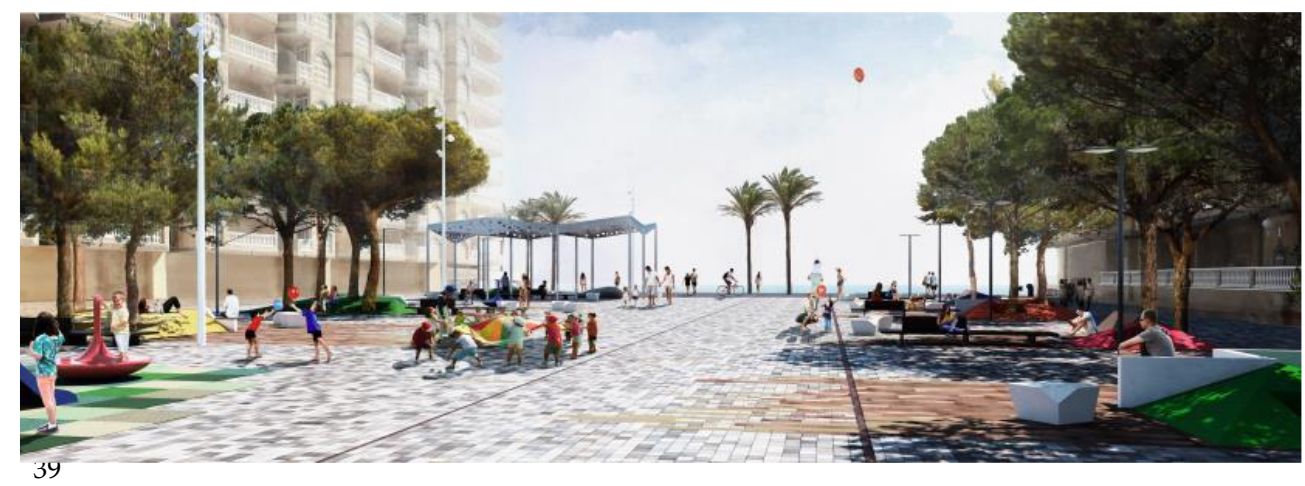

Fig. 2. Plaza Castillos de Mar. Source: Own elaboration

- Developing a Green Corridor. A green corridor is planned along La Gran Vía in La Manga which will progressively extend to the seafront, reaching the emblematic places of the area and collaborating in the construction of a new urban landscape. This corridor will include strips of permeable pavement and trees selected according 
to the principles of xerogardening, so that their treetops offer a passage of continuous shade, thus increasing comfort and forming an urban CO2 sink.

- Design green roofs and façades on buildings, promoting the use of vegetation on roofs and façades, as proposed by A. Vegara in the document: Región de Murcia. Programa Territorios Inteligentes, 2007 [6]..

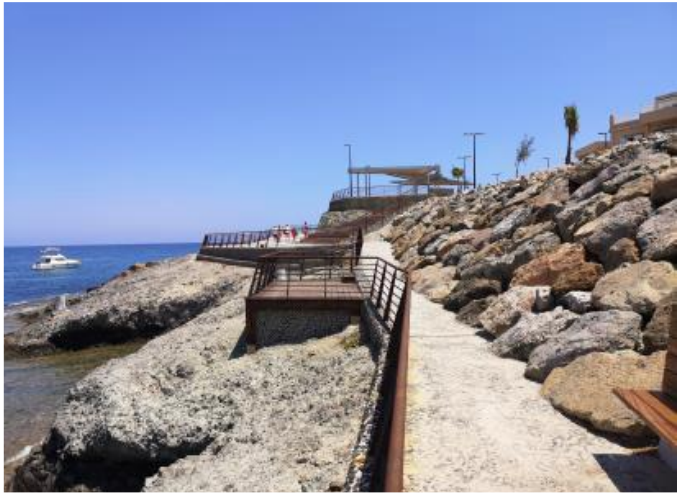

(a)

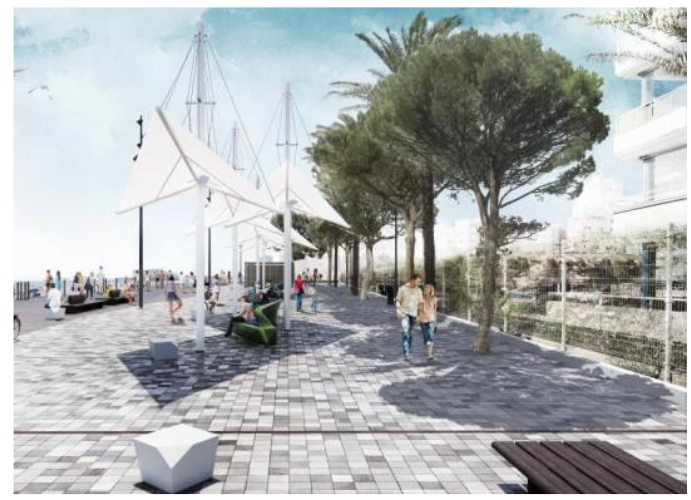

(b)
1

Funding: This research received no external funding.

Conflicts of Interest: The author declares no conflict of interest.

\section{References}

2. Barba, R., pie, R. La marina de Calviá: reflexiones en torno a un proyecto turístico de marina en la isla de Mallorca. Geometría 12.1991

3. Rueda, S. (Dir) (2012). Guía metodologica para los sistemas de auditoria, certificación o acreditación de la calidad y sostenibilidad en el medio urbano. Madrid: Centro de Publicaciones Secretaría General Técnica. Ministerio de Fomento.

4. Mínguez, E. (2015). Tesis Doctoral. Sistema de Polinúcleos Sostenibles (SPS). Estrategia de Revitalización para La Manga del Mar Menor (Murcia). Alicante.

5. Mínguez, E. (2016). Estrategia de Desarrollo Sostenible e Integrado (EDUSI) "La Manga Abierta 365".

6. Vegara, A. (2007). Región de Murcia. Programa Territorios Inteligentes. Madrid: Fundación Metropoli.

7. Revista CUADERNOS № 2 (2019). Arquitectura y Sostenibilidad I. Colegio de Arquitectos de Murcia (COAMU). 